\title{
The Distribution of Zakat: A Comparison between the Rate of Nișāb and the Rate of Poverty Line Income in Malaysia
}

\author{
Muhammad Pisol Mat Isa ${ }^{1}$, Azhan Rashid Senawi², Azhar Harun ${ }^{3}$ \\ 1, 2, 3 Management and Humanities, Universiti Teknologi PETRONAS Bandar Seri Iskandar, 32610 \\ Tronoh, Perak, Malaysia
}

\begin{abstract}
Zakat plays a significant role in Muslim community as an agent in alleviating the poverty. The calculation of zakat payment depends of the calculation of nisab, which is the least amount of zakatable items of a Muslim wealth in one circle year. The zakat is an obligatory duty to a Muslim once the amount of wealth reaches the least level of nisab. This study aims to analyze the relationship between the nișāb amount changes and the poor indication in Malaysia. This is based on the discussion of the contemporary scholars, who claimed that the price fluctuation in the world market impacts the amount of nișāb of zakāt. Relatively, it could affect the poor once the price dropped. Therefore, the comparative analyses of the annually nișāb and poverty line income data from 1993 to 2015 identifies that there is a significant correlation between the facts. Accordingly, it is an alert to the zakāt institution to take a precautionary step in preventing this situation.
\end{abstract}

Keywords- Nișāb of zakāt, gold price, poverty, Malaysia

\section{Introduction}

Nișab is an Arabic word which is linguistically derived from nasaba which means reference or standard, al-Dasuqiy said the word Nisab taken from al-nusub which means al-'Alamah or signage, where it shows the limit or border of wealth in paying a zakat (Al Dasuqiy, 2013). Technically it means a measurement of zakāt, where one is responsible to pay a certain amount once the wealth is equivalent and exceed the minimum level in that particular year. Nișāb is also a tool of differentiating the poor and the affluent (Al Qaradhawi, 1999; Majah, 1952). As mentioned in Hadith as narrated by Muaz bin Jabal that Prophet Muhammad pbuh advised him to take the zakat from the wealthy and surrender to the poor in the region, and the amount of nisab (Imam Bukhari, 2015), Imam al-Bararati mentioned that, anyone who hold the amount of nisab and able to furnish their basic need, so they cannot receive zakat (al-Babarati,2002), the statement shows that the those who have amount of wealth above than nisab is considered as wealthy. In the issue of gold and silver price, it need to take an in depth revision, where the determination of silver or gold as a nișāb, is mainly depended to the demand and supply in the world market. The fluctuation of its price, indeed varies the amount of nișāb for that particular year. For the country that uses silver as the determination of nișāb, then the zakāt of money tends to involve the poor as the contributor of zakāt due to the low of the silver price, as statistically reported during the recent period (Khan, 2000). Based on the facts, as long as the items are classified as the commodity items, then, it could not be averted from any rigorous market activity (Browne, Abbriano, \& Lockwood, 2015). This situation proves that, as happened to the price of silver, it is also likely to happen to the price

${ }^{1}$ Corresponding author: mpisolmatisa@utp.edu.my 
of gold. Thus, this could impact the household, who are categorized as poor and destitute (Abu-Saud, 1988; M Kahf, 1989; Sadeq, 1994). In order to justify the claimed situation by the contemporary scholars regarding the nișāb of zakât that associated with the poor and the destitute, this study will undergo some data comparison in particular to the amount of nișāb changes and the poverty line income data. From this, it will conclude whether the argument meets the facts requirement or otherwise. As to facilitate the discussion, this paper has been structured as follows. The next section 2 and 3 will explore the literature reviews and the methodology of this study. Then, section 4 will present the results and discussion, and finally, section 5 summarizes the findings and the overall conclusion.

\section{Literature Review}

Since a century ago, paper money has been used predominantly all over the world. Gold and silver have no longer been a medium of the transaction since the collapse of Ottoman reign in Turkey. Apparently, the nișāb of money which is 20 dinar of gold and 200 dirham of silver will not be the same as previous due to the factor of demand and supply in the world market (Al Qaradhawi, 1999; see also Kahf, 1989). Thus, it might cause a confusion on how to measure the nișāb either base on the silver or the gold. In this matter, due to the fact of sunnah and $i j m \bar{a}^{c}$, the tendency to use silver as the benchmark of nișāb is definitely unarguable. It is explicitly determined in the holy book, al Quran and hadith and for this reason it is been used in the country of Egypt, Saudi Arabia, the gulf countries, India and Pakistan (Al Qaradhawi, 1999). Some scholars incline to use gold as the benchmark of nișāb due to the aspect of stability compared to the silver. Those who favor to use gold as the nișāb are Abu Zahrah, Khallaf and Hasan (Al Qaradhawi, 1999; Sadeq, 1994). This is due to the current situation where the price of gold is more suitable to be compared to another item such as camel, sheep, and crops than the silver. For instance, nișāb of camel which is 5, or sheep which is 40, are very close to the nișāb of gold, which is 85 grams of gold. Meanwhile, niṣāb of silver which is 595 grams not even equal to one camel price (Kahf, 1989).

There is a hadith that mentions five uqiyyah of the silver nișāb was enough for one's household for their living in one year at very reasonable standard of living and at that specific time (Abu-Saud, 1988; see also Al-Dahlawi, n.d.). However, as the time passes, this measurement could not fit the living standard of today due to the fact of inflation and market instability. It would not be sufficient even for a week. Therefore, the benchmark of nișāb is much more suited to gold, which is at 85 grams of gold. Otherwise, it would inflict the unjustness to the zakāt contributors (Abu-Saud, 1988; Mahmud \& Shah Haneef, 2008; Sadeq, 1994). Furthermore, the instability value of money gives the bad impact to the silver nișāb where the current price shows the low price of silver as compared to gold and other items of wealth. This low price of silver would also decrease the nișāb of zakāt and consequently, it tends to give an effect to the recipients of zakāt especially to those in the group of poor (Sadeq, 1994). That is why gold is more preferable than silver due to the fact of time changing.

Nevertheless, there would also a matter of market price fluctuation, where the price of gold could not be avoided from affecting its value. Certainly, people will ask the matter of the availability from the aspect of shariah in discovering the other item besides the silver and the gold. In this condition, Al Qaradhawi (1999) views that the determination of zakat niṣāb should either be equivalent to one-half of fives camel or forty sheep in that particular country. This is proposed in order to moderate the standard and the purchasing power in the world market due to the tremendous fluctuation of gold prices that could impact the nișāb. Meanwhile, the Muslim council in Pakistan, Majlīs Taḥqīq Masāil Haḍirah has strongly opposed the intention in reviewing the nișāb due to the reason that the determination of nișāb 
is not derived from the ijtihad but it is from the holy book; al Quran, hadith and ijmak or Muslim Jurist's consensus (Mahmud \& Shah Haneef, 2008; Sadeq, 1994). However, they admit that should the value of nișāb increase, it results in a decrease of zakāt contributor and lead to a high of zakāt recipient. Thus, it will create an excess in demand for zakāt and tendency to have a begging culture in the society (Mahmud \& Shah Haneef, 2008; Sadeq, 1994).

On the other side, Raqibuzzaman (1980) insists that the nișāb should be allowed to be changed according to the situation of the country. It is due to the condition that varies from country to another country. In addition, the nișāb is a portion that value the adequate standard of living on that particular time. Thus, the burden should not be borne to the poor and destitute as a result of the low nișāb. This practice also uses the analogy of what has been done by Caliphate Umar, who measures the horse as a zakāt rate (Sadeq, 1994). Narrated in a hadith that reports "Zakāt will not due if it less than 5 camels, while, for grain, it will not due less than 5 awsuq (1300 kilogram) then, for money, it will not due less than 200 dirhams" (Majah, 1952). However, Abu-Saud (1988) affirms that these benchmark was only appropriate for that time being rather than its use today. As for an example, during the time of the Prophet, 5 awsuq was sufficed for a family of three for a year, however, 5 awsuq for a planter in Malaysia nowadays cannot even satisfy their basic needs in a year at all. Due to changing times, it is impractical to use an akin standard of benchmark in order to fulfill the needs of the poor and the destitute (Mahmud \& Shah Haneef, 2008; see also Abu-Saud, 1988). Thus, it needs to be revised in accordance to the principle of Islamic Jurisprudent. Furthermore, Abu-Saud (1988) posits that contribution for zakāt should be based on some criteria, in which, it should take into account the mandatory household expenses (ḥawāij al aṣliyyah), time value of money, inflation and deflation as well as income tax deduction for the zakāt payer. The rationale to review this issue is due to the time changes that affect the value of the nișāb amount, in which it is not parallel to the rise in cost of living and significantly, it changes the basket of essential needs especially to those who are categorized as poor and destitute (Kahf, 1989). Thus, there is a need to tackle this issue in signifying the claim and to clarify the matters that could affect the lives of the poor and the destitute.

Meanwhile, in many countries including Malaysia, the mechanism in identifying the poor is through the Poverty Line Income (PLI). In the case of Malaysia, the PLI is issued by Economic Planning Unit under the Department of Prime Minister. According to the PLI data, there is two categories of poor, known as the absolute poverty and relative poverty (Jamil \& Che Mat, 2014; Mohamed Saladin Abdul Rasool, Mohd Fauzi Mohd Harun, Ariffin Mohd Salleh, 2011; Ragayah, 2010). Under the circumstances of absolute poverty, a person whose income is equivalent or lower than the poverty line is considered as poor. While, the relative poverty quantifies the average of the living standard within the community in that particular year (Jamil \& Che Mat, 2014; Ragayah, 2010). Thus, this study will run a comparison analysis of both data in order to have the significance of the claim by the contemporary scholars. It may consider a general and concrete analysis of the nișāb and the poverty line income in Malaysia in justifying the matter that arises.

\section{Methodology}

This study uses the data from the Economic Planning Unit, Prime Minister's Department for the poverty line income and Pusat Pungutan Zakāt (Center for Zakat Collection), Wilayah Persekutuan for the nișāb of zakāt in comparing the relevancy of the both data. It will cover the year of 1993 to 2015 of the analysis period. It is a qualitative approach that used a content analysis technique in analyzing the data sets. By comparing the observed figures and applying 
the logical inference, it will determine the relevance and the implication that might appear in this analysis. From here, the study concludes the result for the purpose of a future research.

\section{Result and Discussion}

For a discussion, the table of nișāb and the poverty line income are placed in order to facilitate the analysis. The table 1 below shows the details of the both data.

Table 1: The Amount Gap between the PLI and Niṣāb of Zakāt from 1993 to 2015 (RM/ annually)

\begin{tabular}{cccc}
\hline Year & PLI (RM)2 & Nișāb & PLI - Nișāb \\
\hline 1993 & 5160 & 2900 & 2260 \\
1994 & 5160 & 2900 & 2260 \\
1995 & 7320 & 2700 & 4620 \\
1996 & 7320 & 2700 & 4620 \\
1997 & 7320 & 2800 & 4520 \\
1998 & 7320 & 2900 & 4420 \\
1999 & 7800 & 2900 & 4900 \\
2000 & 7800 & 3200 & 4600 \\
2001 & 7800 & 2900 & 4900 \\
2002 & 7800 & 3000 & 4800 \\
2003 & 7800 & 3000 & 4800 \\
2004 & 8280 & 3700 & 4580 \\
2005 & 8280 & 4200 & 4080 \\
2006 & 8280 & 4600 & 3680 \\
2007 & 9000 & 6200 & 2800 \\
2008 & 9000 & 6400 & 2600 \\
2009 & 9600 & 8000 & 1600 \\
2010 & 9600 & 9300 & 300 \\
2011 & 9600 & 10300 & -700 \\
2012 & 10320 & 13113 & -2793 \\
2013 & 10320 & 14066 & -3746 \\
2014 & 11400 & 12223 & -823 \\
2015 & 11400 & 11308 & 92 \\
\hline
\end{tabular}

Source: Pusat Pungutan Zakāt (PPZ) and Economic Planning Unit, Prime Minister's Department

The above table is generalized from the original of both the nișāb of zakāt and PLI data. The data have shown the amount trend of the nișāb and the PLI from 1993 to 2015. Apparently, from this comparison, it is proved that the PLI has been at the level of more than the nișāb of zakāt. It could be detected from the amount of PLI from 1993 to 2010, where these years, the amount of PLI is greater than the nișāb of zakāt. It is not just a tens of RM difference, but it reaches thousands RM. This could clearly be seen from the fourth column. From table 2, it has explained well that the low nișāb is indeed exploiting the poor that based on the PLI data. Accordingly, Kahf (1989), Sadeq (2004) and Mat Isa (2013) argument's on the issue of nișāb, that claim the nișāb changes could ruin the standard of living of the poor is proven. As denoted from the above table, the highest amount gap between the PLI and niṣāb is RM4900,

\footnotetext{
${ }^{2}$ The PLI data have been transformed to annually in order to draw the best fit comparison with the nișāb of zakāt. It is not a yearly assessed data. It is, in fact, a data of once in-four-year. Therefore, the above data produced is to suit the yearly data of nișāb of zakāt in order to have a better comparison between both data. For a quick search, the PLI could be excessed at www.epu.gov.my/.
} 
which is at 1999 and 2001. While, the lowest amount gap is at 2015, where the amount is only RM92. However, on average, most of the accounted year, the PLI has a higher amount than the nișāb. Except for the year 2011 to 2014, where the PLI is amounted low by RM700, RM2793, RM3746 and RM823 respectively. This situation will be more clearly seen from the line graph of figure 1 below.

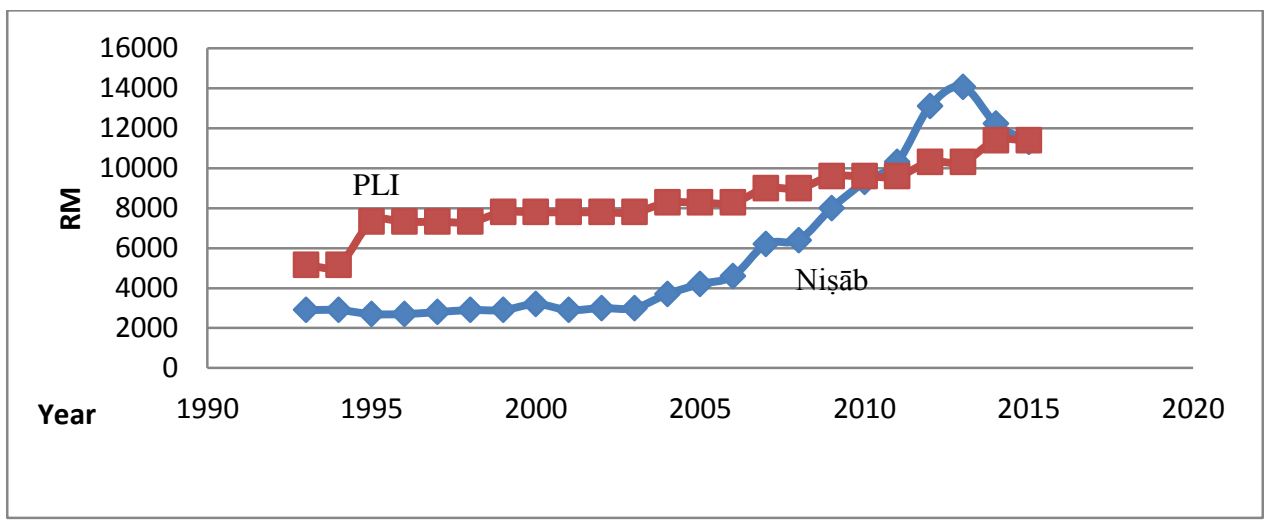

Figure 1: Comparison between the Nisab and the PLI from 1993 to 2015

From the above figure, it clearly shows that the gap between the PLI and the nișāb are significantly explained that the poor earnings exceeds the amount of nișāb as shown by the square dotted line from 1993 until 2010. In other words, this excess signifies how the role of the gold price and the macroeconomic determinants affect the well-being or the standard of living of the poor in terms of the eligibility to pay the zakāt even though they are not eligible (Kahf, 1989; Sadeq, 2004; Mat Isa, 2013). Whereas, in 2011 to 2014, the diamond dotted line of nișāb is seen higher than the PLI due to a high price of gold in the world market. As the Majlīs Taḥqị Masāil Ḥạ̣irah, the Muslim Council in Pakistan claim, this will reduce the collection of zakāt and simultaneously, inhibit the distribution of zakāt to the poor (Mahmud $\&$ Shah Haneef, 2008; Sadeq, 2004). Therefore, from this comparison, it can be summarized that there is a linkage between the nișāb and the poor group. Significantly, the arguments by Kahf (1989), Sadeq (2004) and Mat Isa (2013) as well as Mahmud and Shah Haneef (2008), are reasonable and justify the relationship between the nișāb and the poor, in which, it relates the impact assumption of the nișāb amount changes and the poor group.

Nonetheless, the study opines that these two items (the PLI and the nișāb) need to be scrutinized further. This is due to the progressive and the fluctuation pattern shown by the PLI and the nișāb item respectively. If observed the PLI from 1993 to 2015, it shows a moderate-increase trend from RM430 in 1993 to RM950 in 2015. Undeniably, it could be increased more due to the socioeconomic situation such as the cost of living and the status of the developed country in 2020. Furthermore, the current proposal of the minimum wage in Malaysia, which is at RM1000 to RM1200 by the Malaysian Trades Union Council (Solomon, 2016; Ling, Yusof, Hasnaa, Mahmood \& Soon, 2014) could be also the pull factor of the PLI indication. These could be one of the huge factors that might elevate the PLI in the future because the current PLI is, in fact, portrays the level of the minimum wage for the support civil servants, which is around RM600 to RM900 monthly (Suruhanjaya Perkhidmatan Awam, 2014).

The concern now is the nișāb, where the amount very much depends on the world market price. It could be at a high level and it could be low. As portrayed in the nișāb data from 1993 
to 2015, it begins with RM2900 and gradually increases to RM11308 in 2015. But, during the years of 2012 to 2015, the nișāb is floating from RM13113, RM14066, RM12223 and lastly at RM11308 respectively. This can be clearly viewed in the figure 1, where the graph line plotted the fluctuation of the nișāb higher than the PLI. It raises an issue that, what would happen if the PLI keeps accelerating, but the nișāb continues to down trend as a result of the gold prices volatile in the world market. It seems to bring an indication that the nișāb could probably ruin the virtue of the maqāșid of sharī̄ah of the zakāt. Therefore, it could be concluded that the claim by the Kahf (1989), Mat Isa (2013) and Sadeq (2004) have its own ground to be proved. In fact, it is illustrated well to point out the basis of the argument, when it is assessed in figure 1 of the graph line as well as the tables of the nișāb and PLI above.

\section{Conclusion}

Alms are for the poor and the needy, and those employed to administer the (funds); for those whose hearts have been (recently) reconciled (to Truth); for those in bondage and in debt; in the cause of Allah. and for the wayfarer: (thus is it) ordained by Allah, and Allah is full of knowledge and wisdom' (Quran, 2011). Thus, it is a responsibility of all Muslims to remain alert to any possibility that could affect the poor caused by the economic condition. This is to avoid any possible implication to the poor and destitute by endowing as a rich group, unintentionally due to the changes of nișāb. From the above discussion, it shows that a low nișāb from 1993 to 2010 and 2015 caused the poor to be among the contributor cluster, although, they are among the group, who deserve to be the zakāt recipient. All of this is the consequence of a series, where the PLI that represent the poor is higher than the nișāb. Hence, the claim that the nișāb has a tendency to affect the poor group has its own basis. Therefore, this study provides an opportunity to further a research in signifying the possible patterns of nișāb of zakāt on the poverty line income. An in-depth study could be a novelty contribution to the Muslim society as well as to the zakāt institutions in justifying the issues highlighted.

\section{References}

Abu-Saud, M. (1988). Contemporary Zakāt. Zakāt and Research Foundation, 113.

Al Qaradhawi, Y. (1999). Fiqh al Zakah. Beirut: Dar Al Taqwa,pg. 14.

Al-Dahlawi, S. (n.d.). Hujjatullah al-Balighah. Maktabah al-Kautsar, vol 2, pg. 506.

AL-Dasuqi, Ibn Irfah. (2013), Hasyiah al-Dasuqiy ala Shar al-Kabir, vol. 4.pg 211.

Browne, R., Abbriano, S., \& Lockwood, R. (2015). Gold \& Silver Marketwatch.

Jamil, N., \& Che Mat, S. H. (2014). Realiti Kemiskinan: Satu Kajian Teoritikal. Jurnal Ekonomi Malaysia, 48(1), 167-177.

Kahf, M. (1989). Zakāt: Unresolved issues in the contemporary fiqh. IIUM Journal of Economics and Management.

Kahf, M. (1999). The principle of socio-economic justice in the contemporary Fiqh of Zakah. IQTISAD Journal of Islamic Economics.

Khan, M. (2000). Some Accounting Issues Relating to Zakāh. Islamic Studies, 104-105.

Ling, T. P., Yusof, M. F., Hasnaa, N., Mahmood, N., \& Soon, T. H. (2014). The Implementation of Minimum Wages in Malaysia. Sains Humanika, 2, 43-46.

M. Isa, M. P. (2012). The Implementation of Gold and Silver as the Value of Nișāb for Zakāt Calculation: A Comparative Study between the Present Practices and those during 
the Period of Prophet Muhammad Pbuh. In Kepentingan Dirham Perak dalam Zakāt (pp. 17).

Mahmud, M. W., \& Shah Haneef, S. S. (2008). Debatable issues in Fiqh al-Zakāt: A Jurisprudential Appraisal. Jurnal Fiqh, (5), 118-141.

Majah, I. (1952). Sunan Ibn Majah. Darul Kutub Al Ilmiyyah, Beirut.

Quran, A. (2011). At Tawbah (verse: 60).

Raqibuzzaman, M. (1980). Some Aspects of the Economics of Zakah. Indiana: American Trust Publication

Sadeq. (1994). A Survey of the Institution of Zakah: Issues, Theories, and Administration (Research Paper).

Al-Bukhari, Imam Abu 'Abd 'Allah Muhammad b. Isma'il (1989), Sahih al-Bukhari, Tahqiq Mustafa Bugha, . (Hadith no. 1308),, c. 2, j. 1, Beirut: Dar Ibn Kathir/ 